IZA DP No. 650

\title{
Overeducation and Ethnic Minorities in Britain
}

\author{
Harminder Battu \\ Peter J. Sloane
}

November 2002 


\title{
Overeducation and Ethnic Minorities in Britain
}

\author{
Harminder Battu \\ University of Aberdeen \\ Peter J. Sloane \\ University of Wales Swansea \\ and IZA Bonn
}

Discussion Paper No. 650

November 2002

\author{
IZA \\ P.O. Box 7240 \\ D-53072 Bonn \\ Germany \\ Tel.: +49-228-3894-0 \\ Fax: +49-228-3894-210 \\ Email: iza@iza.org
}

This Discussion Paper is issued within the framework of IZA's research area Internationalization of Labor Markets. Any opinions expressed here are those of the author(s) and not those of the institute. Research disseminated by IZA may include views on policy, but the institute itself takes no institutional policy positions.

The Institute for the Study of Labor (IZA) in Bonn is a local and virtual international research center and a place of communication between science, politics and business. IZA is an independent, nonprofit limited liability company (Gesellschaft mit beschränkter Haftung) supported by the Deutsche Post AG. The center is associated with the University of Bonn and offers a stimulating research environment through its research networks, research support, and visitors and doctoral programs. IZA engages in (i) original and internationally competitive research in all fields of labor economics, (ii) development of policy concepts, and (iii) dissemination of research results and concepts to the interested public. The current research program deals with (1) mobility and flexibility of labor, (2) internationalization of labor markets, (3) welfare state and labor market, (4) labor markets in transition countries, (5) the future of labor, (6) evaluation of labor market policies and projects and (7) general labor economics.

IZA Discussion Papers often represent preliminary work and are circulated to encourage discussion. Citation of such a paper should account for its provisional character. A revised version may be available on the IZA website (www.iza.org) or directly from the author. 
IZA Discussion Paper No. 650

November 2002

\section{ABSTRACT \\ Overeducation and Ethnic Minorities in Britain*}

This study examines the utilisation of education across ethnic minorities in the UK. In particular, we examine the incidence of mismatch between educational qualifications and occupational attainment, the determinants of any mismatch and the consequences for earnings and other labour market outcomes. Using a modal measure of required education across sixty occupations we find that different ethnic groups have varying levels of overeducation with the highest incidence being amongst the Indian and Africa-Asian groups. When we introduce controls we find that the African-Asians are more likely to be both over and under-educated relative to Indians (the omitted group), but this is reversed for those born in the UK. Foreign qualifications increase the likelihood of over-education for Pakistanis and Bangladeshis but reduce it for African-Asians. Language fluency increases the likelihood of mismatch. The results from our earnings regressions support previous work in relation to the returns to over, required and under-education, though with differences between native and immigrant non-whites.

JEL Classification: $\quad 12, \mathrm{~J} 3, \mathrm{~J} 7$

Keywords: ethnic minorities, educational qualifications, mismatch, earnings

Corresponding author:

Harminder Battu

Department of Economics

University of Aberdeen

Edward Wright Building

Dunbar Street

Old Aberdeen, AB24 3QY

Scotland, UK

Tel.: +44 1224272718

Fax: +44 1224272181

Email: h.battu@abdn.ac.uk

\footnotetext{
* We would like to thank the Policy Studies Institute and the Data Archive at the University of Essex for giving us access to the Fourth Ethnic Minorities Dataset. We would also like to thank participants at the European Society for Population Economics, Athens, June 2001 for their comments. We also gratefully acknowledge the detailed comments and suggestions of two anonymous referees.
} 


\section{INTRODUCTION}

There is a substantial literature on the labour market performance of ethnic minorities in both Europe and North America. In the UK, for instance, it is well documented that ethnic groups experience higher unemployment, lower earnings and lower occupational attainment relative to whites (Blackaby et al, 1998, 1999). For the US there are similar findings, albeit with a greater attention to spatial constraints, with the labour market disadvantage faced by AfricanAmericans reflecting a growing suburbanisation of employment opportunities (Kain, 1968, Arnott 1998). A divergence between residential location and employment opportunities makes it harder for blacks to commute or gain knowledge about job opportunities.

Despite a growing literature on whether workers in general are being fully utilised in the workplace very little attention has been paid to over-education amongst ethnic minorities. The broad consensus is that significant numbers of workers are either over-educated or undereducated where over-education occurs where actual education exceeds that formally required for the job and under-education where educational attainment is below that formally required. In the US Sicherman (1991) found that around $40 \%$ of the workforce were over-educated, while $16 \%$ were under-educated. For the UK Sloane et al. (1999) found that around $31 \%$ of British workers were overeducated, $17 \%$ were under-educated and the remainder adequatelyeducated.

In itself this mismatch between educational attainment and requirements need not be a problem. Concern arises when it has a detrimental long-term effect on individual productivity, imposing wage penalties and reducing job satisfaction. Almost without exception, existing empirical studies have found a benefit from surplus education in terms of a positive return to earnings, but also a penalty, since this return is smaller than the return to a perfectly matched worker (Alba Ramirez, 1993; Hartog, 2000; Sloane et al. (1999). With respect to job satisfaction higher attained education brings with it higher expectations in 
terms of challenging and interesting work duties. Incongruity between actual and required education generates worker dissatisfaction (for example, see Tsang et al., 1991). To the extent that higher dissatisfaction generates lower work effort this reduces worker productivity and thus the individual rate of return. Battu et al. (2000), found that graduates who are matched to jobs which require degrees, have higher job satisfaction than those graduates in non-graduate jobs.

As far as we are aware there are no studies that explicitly focus on mismatch amongst ethnic minorities. The limited research evidence that does exist tends to focus on the population at large with a cursory attention to ethnic groups. Nevertheless, the limited research on ethnic groups finds that over-education is greater for non-whites (Duncan and Hoffman, 1981; Alpin et al, 1998) and there is also some evidence to suggest that ethnic minority graduates do experience greater difficulties in accessing "graduate" jobs relative to whites (Connor et al., 1996). In any case the heterogeneous ethnic profile of the non-white population in terms of ethnic origin is not acknowledged and nor is any distinction made between ethnic minorities who are native born and those who are foreign born. This is unfortunate, since it is now well established that economic deprivation is relatively more acute for certain ethnic groups (in the UK this applies to Bangladeshis) and these are more often than not also the most recent arrivals (see, for example, Blackaby et al. 1998 and 1999 and Leslie, 1998).

But why might non-whites have a higher incidence of over-education? Broad explanations revolve around supplies of skills exceeding demand or imperfections in clearing the labour market. An argument specific to non-whites is simply that of discrimination. If non-whites find it more difficult to acquire any job they may well be more likely to take a job that is not commensurate with their qualifications, so that a higher proportion of non-whites end up over-educated. With the level of educational attainment rising amongst ethnic groups as a whole and with ethnic students being comparatively well represented in higher education (Owen et al. 2000) discrimination, if reflected in greater over-education and thus lower 
earnings, may place doubts on the importance of human capital attainment as an avenue for escaping disadvantage (Leslie and Drinkwater, 1999).

Another less developed argument (at least for the UK) focuses on the spatial constraints faced by ethnic groups. Commuting distances for ethnic groups tend to be shorter and this reduces the chances of a better match, thereby increasing the probability of being over-educated. The lack of access to a private vehicle may be the constraining factor here and there is some evidence that a higher proportion of Bangladeshi and Pakistani individuals are likely to walk to work relative to whites (Blackaby et al. 1999). In contrast, McCormick (1986) argues that commute times should be higher for non-whites; the argument being that those with high unemployment and low earnings in their local labour market may be willing to accept more distant employment simply in order to gain employment and thereby raise earnings. This in turn could improve the match and actually reduce over-education amongst non-whites. This is basically an empirical issue. Our own analysis using the British Household Panel Survey found that non-whites do indeed have higher commute times (on average 3 to 4 minutes longer for each journey). Commute times will though be a function of distance and mode of transport with public transport journeys taking longer.

This study attempts to fill the void in the over-education literature and examine the imbalance between educational and occupational attainment for non-whites in the UK. By utilising data from the Fourth National Survey of Ethnic Minorities (FNSEM), it examines three issues. First, what is the incidence of over-education amongst the ethnic groups in the UK? Second, what factors drive any mismatch that they experience? Third, what are the consequences of this mismatch in terms of earnings and other job attributes? It should be emphasised that our basic premise is that over-education is a consequence of discrimination, rather than implying that too much education has been provided for ethnic minorities. The positive return to overeducation serves to emphasise this point. 


\section{DATA}

The data are derived from the Fourth National Survey of Ethnic Minorities (FNSEM) conducted in 1993/94. The dataset includes a standard set of variables capturing individual, demographic and job characteristics (see Modood et al. 1997 for details). This has the advantage that it over-samples ethnic minority groups and explicitly acknowledges the heterogeneity within the non-white population. The upshot is that we must be cautious in comparing averages across white and non-white groups. The ethnic population is composed of six groupings (Caribbean, Indian, Pakistani, African-Asian, Bangladeshi, and Chinese).

The 1991 Census was used to select the sample of ethnic minorities included in the survey. In particular, all 9527 electoral wards in England and Wales were divided into three bands (high, medium and low) according to the proportion of the population who were members of ethnic minorities. Within each band a sample of wards was chosen and within each of these selected wards a sample of addresses was picked. Interviewers then visited 130,000 addresses to identify any members of the target minority groups living there who could then be interviewed. At each household containing adults from ethnic groups, one or two were selected for interview. Two questionnaires were randomly assigned to the two adults selected with the same core set of questions, but a different set of secondary questions. Crucially, a majority of the selected individuals were interviewed by a member of their own ethnic group either in English or in their own language, thereby maximising the response rate and reducing any potential source of bias. Interviews were obtained in 3291 ethnic households and with 5196 ethnic individuals. A comparison sample containing white households was also obtained, generating 2867 white interviews. ${ }^{1}$ Limiting the analysis to those aged 20 to 64 years there are 1764 employed non-whites and 1154 employed whites.

\footnotetext{
${ }^{1}$ The response rates were $61 \%$ for Caribbeans, $74 \%$ for Indians and African Asians, $73 \%$ for Pakistanis, $83 \%$ for Bangladeshis,
} $66 \%$ for Chinese and $71 \%$ for Whites. 
Some descriptive statistics for the two samples are given in Table 1. As is common in previous analysis using this dataset the data throughout is unweighted (Dustmann and Fabbri, 2000; Lindley, 2002). As such care needs to be taken in interpreting our descriptive statistics especially when comparing whites with non-whites.

In general, and relative to whites, it is the case that non-whites tend to be slightly younger and more likely to be married if male (less if female), and fewer live in very low unemployment wards or have a white boss. They are more likely to be in a workplace where there is a trade union or a staff association present and many more work in the public sector. They have lower weekly pay and spatially they are concentrated in the South East and West Midlands. Fewer have supervised or received workplace training and finally the average number of vehicles in their households is lower.

The dataset also contains detailed information on educational qualifications. However, since there is no direct information on years of schooling, our measure of education is the respondent's highest qualification. An added complication is that around three-quarters of the ethnic minorities are immigrants. Though just over half of the Caribbean working age population (55.56\%) are born outside the UK, in excess of $75 \%$ of the other ethnic groups are immigrants and in the case of the African-Asian and Bangladeshis the figure is around $95 \%$. Thus, part of the immigrants' stock of human capital may be accumulated out with the UK and may be less highly valued by employers than UK acquired human capital. Table 2 provides information on the educational profile of our seven ethnic groups. Over three quarters of whites have only UK qualifications compared to nearly a half (47.85\%) of non-whites. Within the non-white category the Caribbeans, who are the earliest entrants into the UK, are closest to whites with around $67 \%$ of them having only UK qualifications. In contrast, just around a fifth of the Bangladeshi group (the latest arrivals) possess only UK qualifications. A quarter of nonwhites possess only foreign qualifications with the highest rates amongst the four South-Asian ethnic groups. $10 \%$ of non-whites possess both UK and foreign qualifications with the highest 
incidence being amongst the Chinese (23.66\%). The Bangladeshi and Pakistani groups stand out, in having a high proportion with no qualifications (50.54\% and $35.24 \%$ respectively).

The fact that non-trivial numbers of ethnic group members hold both foreign and UK qualifications raises the question as to how we treat foreign qualifications in our measure of highest qualification. Shields and Wheatley Price (2002), using the same dataset, take the UK qualifications as the highest. Their argument is that, “....any UK education will have been undertaken at an older age and is therefore likely to be of a higher level." Our analysis of the data reveals, however, that around a quarter of the small number who possess both UK and foreign qualifications have lower UK qualifications. In particular, a detailed inspection of the data reveals that many immigrants who have degree level qualifications from outside the UK tend to have accumulated at a later stage a range of commercial, clerical and other sub-degree qualifications within the UK. These qualifications may represent the normal upgrading of skills and/or an attempt to counteract discrimination against foreign qualifications.

To ascertain each respondent's highest qualification we make two alternative assumptions about foreign qualifications. First, we treat UK and foreign qualifications as equivalent (highqual) and second, given the small numbers involved and where respondents possessed both we decided to treat UK qualifications as the highest (highqual1). In both cases, we generate six education dummies: no qualifications, commercial and apprenticeship, O-levels, A-levels, vocational degrees, (teaching, nursing and other qualifications) and degree (including both first and postgraduate degree levels). Tables 3 provide a breakdown of the educational attainment of various ethnic groups for both measures of highest qualification. ${ }^{2}$ The distributions are quite similar across the two measures though for some groups (Indian and Bangladeshi) there are lower percentages with a degree under highquall. Regardless of measure the table reveals that the Chinese community and to a lesser extent Indians and 
African-Asians are much more likely to have a degree than whites, whilst fewer Caribbeans possess a degree. In accordance with Table 2 the incidence of no qualification is strongest amongst the Bangladeshi and Pakistanis. These wide differences across ethnic groups are found elsewhere (see for example, Cabinet Office, Performance and Innovation Unit, 2002) and do suggest that any analysis that focuses simply on whites and non-whites may not be very revealing and could potentially be misleading.

Another aspect of the disadvantage of ethnic minority groups is their clear occupational crowding into less prestigious and low paid jobs. Indeed some ethnic groups, despite their educational attainment, may lag behind whites in terms of occupational attainment reflected in higher over-education. There is evidence (not reported here) that non-white workers have a lower representation in the managerial and professional groups relative to whites and are much more highly represented in the lowest manual occupational groupings. In particular, excluding the White and Chinese groups, over $20 \%$ of the remaining groups are in the lowskilled/unskilled categories (for the Indian and Pakistani groups the figures are in excess of $30 \%$ ). Nearly half of Bangladeshi men and well over half of Bangladeshi females are in junior non-manual and personal services, predominantly restaurant work. ${ }^{3}$ Three groups, namely Whites, African-Asian and Chinese are also found to have relatively high concentrations in the managerial and professional categories.

In summary, the data on educational and occupational attainment does reveal considerable heterogeneity across the ethnic groups. Our next step is to try and ascertain the extent of mismatch between educational and occupational attainment across the groups. The overeducation literature points to three ways in which mismatch can be measured. The first measure involves the systematic evaluation by professional job analysts who try to decipher the level and type of education required in particular occupations. The most commonly used

\footnotetext{
${ }^{2}$ We do not split the data by gender as the regression analysis shows that there are no significant gender differences with respect to over-education and also doing so would reduce sample size. For similar reasons we have not attempted to deal with potential problems of sample selection.

${ }^{3}$ According to Modood et al. (1997) “...more than half of all employed Bangladeshi men have just one occupation; waiting and kitchen work in restaurants".
} 
of these evaluations is the Dictionary of Occupational Titles (DOT) established by the US Employment Service. The second measure involves a worker making an assessment of his or her own job. In the US, the Michigan Panel Study of Income Dynamics (PSID) asks, "How much formal education is required to get a job like yours?" The extent of over-education is determined by comparing the required level of education with that actually attained. The third measure focuses on the distribution of educational qualifications in a given occupation. In particular, a comparison is made between the mean or modal level of education for an occupation and that actually attained. Under a variant of this, over-education is defined as one standard deviation above the mean qualification level for that occupation. The problem with this method is that the choice of one standard deviation seems rather arbitrary. Furthermore, the use of one standard deviation forces symmetry into the measure so that the extent of over and under-education is equalised. There is no reason why this should be the case and the other measures routinely find that the proportion of workers who are over-educated is larger than the proportion under-educated.

In our study we make use of modal rather than a mean approach (Table 4). Required education is simply equal to the modal level of education for that individual's occupation. Given that highqual and highqual1 have similar distributions we use highqual as our measure of highest qualification. A worker would then be considered over-educated if his or her actual education exceeded the modal value of education for their occupation, adequately educated if actual education equalled the modal level of required and under-educated if their actual education was lower than the modal required. The mode measure has the advantage that it is less sensitive to outliers and to technological and workplace change (Kiker et al. 1997). Bearing in mind that we might obtain unreliable estimates where we have too few cases in some occupations we use occupations disaggregated at the 2-digit rather than 3-digit level. Where occupations have less than 10 observations it was decided to merge the occupation with the appropriate and adjacent occupation. Having done this we end up with 60 occupational groups. For each of these groups we use the modal level of education as the 
required level of education and calculate mismatch by comparing this with the attained level of education.

Our estimates in Table 4 reveal that around about a third of non-whites are over-educated, with $17 \%$ under-educated and the remainder adequately educated. The highest incidence of over-education is amongst Indians at around 39\% and the Bangladeshis seem to be well matched with approximately $61 \%$ of them being in jobs where they are fully utilised. Where foreign qualifications are downgraded relative to UK qualifications (highqual1) the incidence of mismatch across our various ethnic groups is largely unchanged though the incidence of over-education falls slightly for the South-Asian groups.

\section{EMPIRICAL METHODS}

\subsection{Determinants of mismatch}

A multinomial logit model is used to investigate the determinants of over and undereducation. Our multinomial logit model estimates two sets of coefficients, $\beta_{1}$ (over-educated) and $\beta_{3}$ (under-educated) using the modal measure of mismatch. From these two sets of coefficients we can calculate the probability $P_{i j}$ of individual $i$ being over-educated $(j=1)$ or under-educated $(j=3)$, conditional on a vector of characteristics $x_{i}$.

The probability of individual $i$ being in over (under) education group $j$ (relative to the probability of being in the default group 2 - adequately educated) is given by:

$$
\frac{P_{i j}}{P_{i 2}}=\exp \left[x_{i}^{\prime}\left(\beta_{j}-\beta_{2}\right)\right] \text { for } \mathrm{j}=1,3
$$

With normalisation of $\beta_{2}$ to equal 0 to permit identification of the model, the probabilities are:

$$
P_{i 2}=\frac{1}{\left[1+\sum_{j=1,3} \exp \left[x_{i}^{\prime} \beta_{j}\right]\right]} \quad \text { for } \mathrm{j}=2
$$




$$
P_{i j}=\frac{\exp \left\lfloor x_{i}^{\prime} \beta_{j}\right\rfloor}{\left[1+\sum_{j=1,3} \exp \left[x_{i}^{\prime} \beta_{j}\right]\right]} \quad \text { for } \mathrm{j}=1,3
$$

Separate regressions are run for non-whites and whites and separate ethnic dummy variables are included in the former. The Chinese are, given their small numbers, excluded from our analysis and the Pakistani and Bangladeshi groups combined given their similarities and also the fact that the sample size for the Bangladeshis is below one hundred. The omitted category is Indian. Too few cases precluded running separate regressions for each ethnic group. Our specification of $x_{i}$ also includes demographic variables (age, age squared, gender, marital status) and a range of job and work related characteristics (workplace size, trade union at the workplace, public sector, training, supervision).

An important characteristic of ethnic minorities is their concentration within ethnic enclaves that generally exhibit high unemployment (Peach, 1996). According to assimilation theory, interactions between ethnic minorities and the white majority improve ethnic minorities' social capital and job finding networks (Weinberg, 2000). The assimilation process may be hindered by the concentration of individuals from the same ethnic group. To capture the influence of spatial constraints and ethnic enclaves we incorporate a range of variables: having a white boss; being UK born (the argument being that immigrants are more likely be resident in enclaves); the concentration of own ethnic group at a ward level and the number of vehicles in the household (see Raphael and Stoll, 2000 for an analysis of how car ownership influences labour market outcomes). To capture unemployment at a local level we use information on the unemployment rate at the ward level. We find that over $70 \%$ of the white sample lives in a ward with an unemployment rate of less than $10 \%$. This compares with approximately $17 \%$ and $11 \%$ for the Pakistani and Bangladeshi groups respectively. As discussed above another key part of a migrants profile is foreign qualifications. To ascertain 
the extent to which foreign qualifications influence job matches we also include a foreign qualifications dummy in our estimating equation.

\subsection{Earnings}

Our earnings estimates are complicated by the fact that earnings in the dataset are observed to fall in a certain interval on a continuous scale. Individuals were asked to indicate which of sixteen weekly income bands best encapsulated their income. This refers to usual gross pay from their main job including overtime and bonuses before any deductions. The advantage of earnings bands is that individuals may be more accurate when asked to place their earnings in a band compared to where they are asked to give a precise figure. On the other hand around $20 \%$ of observations on earnings are missing and though the response rate was good for some groups (Whites, Caribbean, Bangladeshi and Chinese) the response rate was poor amongst Indians and Pakistanis. Modood et al. (1997) suggests that the "missing" are likely to fall disproportionately into the high earnings group so that mean levels of earnings may be understated. Nevertheless, it is comforting to find that mean earnings using midpoints are significantly lower for non-whites overall with Bangladeshis having the lowest earnings and African-Asians and the Chinese displaying parity with Whites. Rather surprisingly Indian mean earnings were below those of the Caribbeans given the formers' job-level distribution. The mean earnings for Indians are clearly depressed and this reflects their higher refusal rate in the survey.

Two estimation methods were utilised. Our first approach uses mid-points and produces estimates using least squares (OLS). ${ }^{4}$ According to Stewart (1983) this ad hoc procedure may generate inconsistent estimates. Hence, we also employ an interval regression model where the dependant variable (earnings) is categorical and ordered and the cut-off points are known.

\footnotetext{
${ }^{4}$ The dependent variable (the log of weekly earnings) takes the midpoint of 16 bands with the upper limit of the final band determined by multiplying the lower threshold (789) by 1.5 . This procedure has been used by Chiswick and Miller (1995) and Lindley (2002).
} 
This is a maximum likelihood estimator and generates consistent estimates of the parameter values.

Assuming a model structure of the following form for individual $i$ (where $i=1,2, \ldots, \mathrm{N}$ ):

$$
y_{i}=x_{i}^{\prime} \beta+\mu_{i}
$$

where $y_{i}$ is our unobserved observation $i$ of (continuously distributed) the log of earnings, $x$ is a vector of regressors, $\beta$ our unknown parameters and $\mu_{i}$ is the random error term. Under the assumption of conditional lognormality of earnings,

$$
y_{i} \mid x_{i} \sim N\left(x_{i}^{\prime} \beta, \sigma^{2}\right)
$$

With $K$ groups (here we have 16 bands), the $k$-th is given by $\left(A_{k-1}, A_{k}\right)$ and $A_{0}=-\infty$, and $A_{k}=+\infty$.

In practice the OLS and internal regression method produced very similar results, so only the latter are reproduced here.

The specification of our earnings equation is grounded in an assignment framework (Sattinger, 1993) in which we have a supply-side (what workers bring to the labour market in terms of educational qualifications) and a demand-side (the requirements of the firm in terms of educational qualifications). Traditional human capital and job competition approaches are seen as special cases where either the supply or demand side is suppressed. For example, in a standard human capital specification earnings are largely a function of the supply-side and in particular individually attained education and experience. Here the demand-side, and in particular, required education plays no role.

The assignment specification includes a required education variable $\left(\mathrm{S}_{\mathrm{r}}\right)$ and dummies for over $\left(\mathrm{S}_{\mathrm{o}}\right)$ and under-education $\left(\mathrm{S}_{\mathrm{u}}\right)$. The omitted category is adequately educated. Other 
controls $\left(\mathrm{z}_{\mathrm{i}}\right)$ included are age and its square, dummies for gender, marital status, industry, and region of residence. The regressions are run separately for whites and non-whites and to gauge the importance of assimilation effects separately for native and non-native non-whites. The earnings function has the form:

$$
\ln y_{i}=\beta_{i} z_{i}+\chi_{i} S_{r}+\eta_{i} S_{o}+\theta_{i} S_{u}+\varepsilon_{i}
$$

\subsection{Supervision and Training}

Alongside the effects on earnings we also investigate the effects of over-education on two other work related characteristics, namely whether individuals have ever supervised others in the workplace and whether they have received workplace training. The extent to which individuals have supervisory responsibilities can be seen as a measure of job level and labour market success. In particular, all employees were asked "Do (did) you supervise, or are(were) you responsible for other people's work? ${ }^{5}$ The training question is "Since completing fulltime education, have you ever done any training for the workplace?" One argument might be that the overeducated receive less training than properly matched workers, as less training is required to perform their job because their education provides them with sufficient skills that compensate for the lack of training. On the other hand it is possible that education and training are complementary. Binary probit models are run with the dependent variables being supervision (yes/no) and training (yes/no). The covariates in both regressions include dummies for over and under-education as well as our required education variable.

${ }^{5}$ It has been found that individuals in non-manual jobs are more likely to supervise compared to those in manual jobs (Modood $e t$ al. 1997). 


\section{EMPIRICAL RESULTS}

The results for our multinomial logit regressions are given in Tables 5 and 6 with coefficients and marginal effects reported for non-whites and whites respectively. The results reveal the following. ${ }^{6}$ Being over-educated decreases with age (with more work experience). Gender and marriage have no significant effect on the probability of being matched or otherwise. Rather surprisingly and contrary to assimilation theory being UK born and being fluent increases the likelihood of mismatch (both over and under-education). Workers with foreign qualifications are more likely to be over-educated suggesting that foreign qualifications are not as highly valued by employers. Of the ethnic dummy variables only African-Asians have a significantly greater likelihood of being mismatched relative to the omitted category of Indians (a marginal effect of 0.15).

We also constructed a number of interaction terms. From these it is evident that AfricanAsians who are born in the UK and who have foreign qualifications are less likely to be overeducated. By way of contrast Pakistani and Bangladeshi workers with foreign qualifications have a higher probability of over-education. This difference in the effect of foreign qualifications across the two ethnic groups may reflect the higher quality of the Africa-Asian ethnic group.

The effects of being resident in an ethnic enclave for non-whites are captured via a banded continuous variable for ethnic concentration. Here we find that a worker belonging to a ward with high ethnic concentration has a greater probability of being over-educated. The existence of poor matches in wards with higher ethnic concentrations suggests that ethnic enclaves do not help the matching process. This, however, is not the case with whites, since for them the

\footnotetext{
${ }^{6}$ A number of tests were carried out for the multinomial logit regressions. First, both likelihood ratio and Wald tests were carried out to test whether the independent variables differentiate between the two outcomes. Both tests reject the idea that the two
} 
probability of being over-educated actually falls with ethnic concentration at the ward level (Table 6). Having a white boss may signal whether non-white individuals have managed to break out of ethnic enclaves and are no longer employed by someone of their own community. From our descriptive statistics in Table 1 it is evident that just under a quarter of non-whites have a non-white boss. For non-whites having a white boss increases the likelihood of over-education, though this is only significant at the $10 \%$ level. This is indicative not of hiring discrimination since workers are employed, but perhaps that white bosses are less likely to recognise foreign qualifications relative to non-white bosses.

Being employed on shifts raises the likelihood of over-education for non-whites and reduces the likelihood of under-education for whites. This is consistent with responsibility for sharing capital equipment raising the requirement for appropriate levels of education. Public sector employment reduces the likelihood of over-education for non-whites and whites. This is consistent with credentialism being more important in this sector. Likewise having had responsibility for supervision reduces the likelihood of over-education for both non-white and white workers. Having undergone training reduces the probability of being over-educated for non-whites only. There is no evidence that the number of vehicles in the household, by widening the area of job search, has any significant effect on job matching.

The results for our earnings equation estimations are given in Table 7 for non-white immigrants, non-white natives and whites respectively. Across all three samples there is an earnings premium associated with required education, with the smallest premium being for UK born non-whites. The premium associated with surplus education is positive for nonwhite immigrants $(7.3 \%)$ and whites $(13 \%)$ but smaller than that for required education. There is no evidence of a positive premium associated with over-education for UK born non-whites. In general, these estimates are not out of kilter with previous studies. Groot and Maasen van

outcomes are indistinguishable. Second, the Hausman and Small-Hsiao tests of the independence of irrelevant alternatives (IIA) assumption were carried out. These tests reveal that the IIA assumption is not violated. 
den Brink (2000) in their meta-analysis covering the US and a number of European countries have estimated the rate of return to surplus education to be $2.6 \%$ over the last 30 years. However, we need to bear in mind that our analysis covers all degrees of over-education. Sloane et al. (1999) found a positive return of $2.8 \%$ for each level of surplus education with the overall rate being $14 \%$ (similar to the rate for whites in our estimates). With respect to under-education we find that earnings are discounted; the negative return to under-education ranges from around 12 to $31 \%$, with the penalty being higher for non-native non-whites. The consensus in the literature is that the returns to under-education are negative and that the penalty for under-education tends to be smaller than the returns to required education (Hartog, 2000). We confirm the former and find the latter only for whites.

Throughout our results we find an earnings premium for males, though the gender gap in earnings is found to be greater for whites and smaller for non-white immigrants. Examining the ethnic dummies we find that, with the addition of controls, three of the ethnic dummy variables coefficients are positive, but small and poorly determined. Only the Caribbean ethnic group has a positive and significant estimated coefficient albeit at $10 \%$ significance.

Spatial and assimilation effects are evaluated through four sets of covariates. Fluency in speaking the English language is very important for non-white immigrants with an earnings premium of around $10 \%$ where fluency is based on interviewers' evaluation of respondents' speaking ability (those whose abilities were fluent were coded 1 and those with fair, poor or none coded 0 ). This compares with $16 \%$ in a study by Dustmann and Fabbri (2000) and 14 to $20 \%$ for males across a range of specifications in a study by Lindley (2002). Years since migration have no significant effects on earnings for non-white immigrants. There is also no evidence of a positive enclave effect when we examine the ethnic concentration variable. This contrasts with other work suggesting that enclaves offer some form of warm embrace that helps immigrants to escape the discrimination they encounter elsewhere in the labour market. Edin et al. (2000) find that the earnings gain associated with a one standard deviation increase 
in ethnic concentration was around $7 \%$. Having access to private transport may be a mechanism for escaping from an enclave. The individual lives in the enclave and thereby enjoys certain cultural benefits but has longer commutes to jobs. A rise in the number of vehicles in the household, by raising the potential area of job search, is associated with higher earnings for both non-white samples. Though car ownership may be endogenous the results do suggest that having access to a car is an important determinant of earnings for non-whites. No such relationship is discernible for whites. Alternative specifications of the earnings equations incorporated a dummy for foreign qualifications. The dummy for foreign qualifications was found to be insignificant and the coefficients on the other variables remained largely unchanged.

Other results worth mentioning are that weekly earnings rise with age and that both whites and non-white immigrant employees in large establishments (over 500 employees) enjoy an earnings premium. There is no suggestion of a wage curve effect at the ward level, since no relationship between living in a ward with higher unemployment and earnings was detected. Living in the South-East of England is clearly associated with higher earnings for all three groups. $^{7}$ Examining our socio-economic groups it seems that that non-whites obtain an earnings premium in minerals, engineering, other manufacturing and hotels relative to the omitted category (energy).

Tables 8 and 9 provide the coefficients and marginal effects from our supervision and training probits for non-whites and whites respectively. The supervision probit reveals the following. First, and not surprisingly, workers who are fluent in speaking English are more likely to have supervised others (with a marginal effect of 0.23 ). Second, and for both whites and nonwhites the likelihood of supervising increases with required years of education and declines with under-education. In the training regressions there is a positive relationship between

\footnotetext{
${ }^{7}$ The 1991 Census of Population shows that around 45\% of the ethnic minority population is located in London. In our dataset the ethnic population is concentrated in two areas: London (South East) and the West Midlands.
} 
required education and training. There is also evidence that over-education and training are complements rather than substitutes since over-educated workers are more likely to have received work related training. Examining the whites only regression we find that those who are employed in large firms, work in the public sector and have a trade union in their workplace are more likely to have received workplace training. Caribbeans are more likely to be recipients of training.

\section{CONCLUSIONS}

Though there has been a burgeoning of research into over-education across Europe and the US very little of this work focuses on ethnic minorities. The limited research that does exist tends to ignore the clear heterogeneity within the ethnic population. This is especially important in the context of the UK where there exists a diverse ethnic population, many of who were immigrants from Commonwealth countries.

This study undertakes the first analysis of ethnic minority mismatch that acknowledges this diversity, using the Fourth National Survey of Ethnic Minorities conducted in 1994. Our results suggest the following. We find that over-education is higher for non-whites relative to whites. However, this disguises some important differences within the non-white sample. In particular, when incorporating foreign qualifications into our measure we find that all ethnic minority groups display levels of over-education in excess of $30 \%$. Furthermore, undereducation is lower for all ethnic minority groups than for the white population. When we introduce controls in our examination of the determinants of mismatch we find that the African-Asian group are more likely to be over-educated relative to Indians, the omitted category. In addition, foreign qualifications, being UK born and language fluency all raise the likelihood of being over-educated and under-educated. This runs counter to the arguments of assimilation theory. 
The results from our earnings regressions support previous work in finding a positive return to surplus education, a positive and higher return to required education and a negative return to under-education. Further doubts are placed on assimilation theory by our findings that UK born non-whites have the lowest returns to required education compared to non-white immigrants and whites and receive no discernible premium from being over-educated. The results vis-à-vis our enclave variables are less clear-cut when it comes to earnings. On the one hand, the longer the stay in the UK and the greater the access to private transport the higher are ethnic earnings. On the other hand, increases in own ethnic concentration raise earnings. One explanation for this might be that employers in enclaves recognise foreign qualifications. In our examination of supervision and training we find that over-educated non-whites are more likely to have received training and under-educated non-whites are less likely to have acted in a supervisory position compared to those who are perfectly matched. 
Table 1: Means and standard deviations of selected variables

\begin{tabular}{lcccccc}
\hline & \multicolumn{5}{c}{ Non-whites } & \multicolumn{3}{c}{ Whites } \\
\hline Variable & Obs & Mean & Std. & Obs & Mean & Std. \\
Age & 1764 & 36.761 & 10.149 & 1154 & 38.146 & 10.799 \\
Male & 1764 & 0.617 & 0.486 & 1154 & 0.441 & 0.497 \\
Married & 1764 & 0.774 & 0.418 & 1154 & 0.716 & 0.451 \\
Indian & 1764 & 0.275 & 0.447 & & & \\
Caribbean & 1764 & 0.301 & 0.459 & & & \\
Africa-Asian & 1764 & 0.190 & 0.392 & & & \\
Pakistani & 1764 & 0.129 & 0.335 & & & \\
Bangladeshi & 1764 & 0.053 & 0.224 & & & \\
Chinese & 1764 & 0.053 & 0.224 & & & \\
Fluent & 1734 & 0.748 & 0.434 & & & \\
Years since migration & 1303 & 22.220 & 8.879 & & & \\
Ward unemployment $<5 \%$ & 1764 & 0.046 & 0.209 & 1154 & 0.238 & 0.426 \\
Ward unemployment 5-10\% & 1764 & 0.249 & 0.432 & 1154 & 0.550 & 0.498 \\
Ward unemployment 10-15\% & 1764 & 0.284 & 0.451 & 1154 & 0.165 & 0.371 \\
Ward unemployment 15-20\% & 1764 & 0.159 & 0.366 & 1154 & 0.028 & 0.164 \\
Ward unemployment $>20 \%$ & 1764 & 0.262 & 0.440 & 1154 & 0.019 & 0.137 \\
Own group concentration $<5 \%$ & 1764 & 0.334 & 0.472 & 1154 & 0.824 & 0.381 \\
White boss & 866 & 0.764 & 0.425 & 1138 & 0.972 & 0.165 \\
Weekly pay & 1408 & 241.111 & 159.088 & 1072 & 267.998 & 181.824 \\
Workplace size 500 plus & 1581 & 0.163 & 0.370 & 1125 & 0.170 & 0.376 \\
Trade union at work & 854 & 0.405 & 0.491 & 1146 & 0.337 & 0.473 \\
Public sector worker & 839 & 0.417 & 0.493 & 1111 & 0.332 & 0.471 \\
North & 1764 & 0.011 & 0.106 & 1154 & 0.117 & 0.322 \\
Yorkshire and Humberside & 1764 & 0.060 & 0.237 & 1154 & 0.100 & 0.300 \\
East Midlands & 1764 & 0.043 & 0.202 & 1154 & 0.062 & 0.242 \\
South East & 1764 & 0.579 & 0.494 & 1154 & 0.287 & 0.452 \\
South West & 1764 & 0.009 & 0.092 & 1154 & 0.143 & 0.350 \\
West Midlands & 1764 & 0.208 & 0.406 & 1154 & 0.103 & 0.304 \\
North West & 1764 & 0.054 & 0.227 & 1154 & 0.070 & 0.256 \\
Wales & 1764 & 0.015 & 0.121 & 1154 & 0.025 & 0.157 \\
East Anglia & 1764 & 0.022 & 0.145 & 1154 & 0.093 & 0.290 \\
Supervised & 1745 & 0.271 & 0.445 & 1151 & 0.407 & 0.492 \\
Training & 861 & 0.396 & 0.489 & 1147 & 0.586 & 0.493 \\
Number of cars in household & 1750 & 1.100 & 0.751 & 1147 & 1.308 & 0.765 \\
\hline & & & & & & \\
\hline
\end{tabular}


Table 2: Qualifications across ethnic groups (\%)

\begin{tabular}{llllllll}
\hline & Whites & Caribbean & Indian & $\begin{array}{l}\text { African } \\
\text { Asian }\end{array}$ & Pakistani & Bangladeshi & Chinese \\
& & & & & & \\
\hline UK only & 77.38 & 67.42 & 37.94 & 47.16 & 32.60 & 21.51 & 53.76 \\
Foreign only & 1.56 & 3.95 & 24.74 & 20.30 & 23.79 & 19.35 & 7.53 \\
UK and foreign & 1.65 & 5.08 & 11.13 & 11.04 & 7.93 & 8.60 & 23.66 \\
No qualifications & 19.15 & 23.54 & 25.98 & 21.19 & 35.24 & 50.54 & 15.05 \\
$\mathrm{~N}$ & 1154 & 531 & 485 & 335 & 227 & 93 & 93 \\
\hline
\end{tabular}


Table 3: Highest qualifications using highqual (highqual1) (\%)

\begin{tabular}{llllllll}
\hline & Whites & Caribbean & Indian & $\begin{array}{l}\text { African- } \\
\text { Asian }\end{array}$ & Pakistani & Bangladeshi & Chinese \\
\hline Degree & $13.86(13.52)$ & $5.84(5.65)$ & $26.80(20.82)$ & $20.90(19.10)$ & $16.30(14.10)$ & $17.20(12.90)$ & $30.11(27.96)$ \\
Vocational & $13.08(13.17)$ & $15.25(15.25)$ & $7.42(8.87)$ & $7.16(7.76)$ & $5.29(5.29)$ & $0.00(1.08)$ & $21.51(21.51)$ \\
A-level & $16.46(16.64)$ & $14.31(14.31)$ & $12.37(13.20)$ & $18.81(19.40)$ & $11.89(13.22)$ & $8.60(8.60)$ & $15.05(15.05)$ \\
O-level & $24.87(24.87)$ & $28.81(29.00)$ & $18.56(19.18)$ & $25.07(25.07)$ & $23.79(24.23)$ & $15.05(15.05)$ & $11.83(13.98)$ \\
Commercial & $12.48(12.56)$ & $11.68(11.68)$ & $8.04(11.13)$ & $6.57(7.16)$ & $4.85(5.29)$ & $7.53(10.75)$ & $6.45(6.45)$ \\
None & $19.25(19.24)$ & $24.11(24.11)$ & $26.80(26.80)$ & $21.49(21.49)$ & $37.89(37.89)$ & $51.61(51.61)$ & $15.05(15.05)$ \\
N & 1154 & 531 & 485 & 335 & 227 & 93 & 93 \\
\hline
\end{tabular}

Note: Highqual1 in parenthesis treats UK qualifications as the highest attained level of education, whereas highqual treats UK and foreign qualifications as equivalent. 
Table 4: Educational mismatch (\%)

\begin{tabular}{llllllll}
\hline & Whites & Caribbean & Indian & $\begin{array}{l}\text { African- } \\
\text { Asian }\end{array}$ & Pakistani & Bangladeshi & Chinese \\
\hline Over-education & 29.38 & 30.89 & 39.18 & 38.21 & 35.68 & 33.33 & 31.18 \\
Adequately educated & 41.59 & 48.40 & 41.95 & 44.48 & 48.90 & 61.29 & 58.06 \\
Under-educated & 29.03 & 20.72 & 15.88 & 17.31 & 15.42 & 5.38 & 10.75 \\
$\mathrm{~N}$ & 1154 & 531 & 485 & 335 & 227 & 93 & 93 \\
\hline
\end{tabular}

Note:

Pearson chi2 $(10)=30.2559 \mathrm{Pr}=0.001$ (non-whites only)

Likelihood ratio chi2 (10) $=31.9943 \mathrm{Pr}=0.000$ (non-whites only) 
Table 5: Determinants of mismatch(multinomial logit): non-whites

\begin{tabular}{|c|c|c|c|c|}
\hline & \multicolumn{2}{|c|}{ Over-education } & \multicolumn{2}{|c|}{ Under-education } \\
\hline Age & $\begin{array}{l}\text { Coeff. } \\
-0.209(2.78)^{* * *}\end{array}$ & $\begin{array}{l}\text { Marginal effect } \\
-0.044\end{array}$ & $\begin{array}{l}\text { Coeff. } \\
-0.033(0.36)\end{array}$ & $\begin{array}{l}\text { Marginal effect } \\
0.006\end{array}$ \\
\hline Agesq/100 & $0.207(2.24)^{* *}$ & 0.044 & $0.025(0.22)$ & -0.007 \\
\hline Male & $0.165(0.79)$ & 0.023 & $0.263(1.03)$ & 0.025 \\
\hline Married & $0.143(0.57)$ & 0.033 & $-0.056(0.19)$ & -0.014 \\
\hline UKborn & $0.958(1.91)^{*}$ & 0.107 & $1.56(2.76)^{\star * \star}$ & 0.175 \\
\hline Foreign qualifications & $2.482(6.18)^{\star * *}$ & 0.523 & $0.597(1.02)$ & -0.076 \\
\hline Caribbean & $0.142(0.32)$ & 0.017 & $0.271(0.56)$ & 0.029 \\
\hline African-Asian & $0.918(2.50)^{\star *}$ & 0.153 & $0.902(2.05)^{\star *}$ & 0.069 \\
\hline Pakistan/Bangladeshi & $-0.594(1.19)$ & -0.115 & $-0.110(0.18)$ & 0.012 \\
\hline UKborn*Caribbean & $0.030(0.05)$ & 0.043 & $-0.903(1.34)$ & -0.095 \\
\hline UKborn*African-Asian & $-2.004(1.99)^{\star *}$ & -0.254 & $-1.562(1.40)$ & -0.099 \\
\hline UKbornPakistani/Bangladeshi & $-0.345(0.45)$ & -0.034 & $-1.233(1.33)$ & -1.00 \\
\hline Foreign qualifications ${ }^{*}$ Caribbean & $-1.003(1.30)$ & -0.202 & $0.693(0.81)$ & 0.168 \\
\hline Foreign qualifications*Africa-Asian & $-1.435(2.39)^{\star *}$ & -0.227 & $-0.198(0.25)$ & 0.022 \\
\hline Foreign qualifications ${ }^{*} \mathrm{Pak} /$ Bangladeshi & $1.307(1.85)^{\star}$ & 0.261 & $0.752(0.73)$ & 0.008 \\
\hline Fluent & $1.177(4.01)^{\star \star *}$ & 0.188 & $1.13(2.70)^{* \star *}$ & 0.083 \\
\hline Ward unemployment 5-10\% & $-0.026(0.05)$ & -0.065 & $1.023(1.48)$ & 0.159 \\
\hline Ward unemployment $10-15 \%$ & $-0.114(0.22)$ & -0.06 & $0.672(0.93)$ & 0.103 \\
\hline Ward unemployment $15-20 \%$ & $-0.105(0.19)$ & -0.061 & $0.687(0.89)$ & 0.110 \\
\hline Ward unemployment over $20 \%$ & $-0.370(0.66)$ & -0.118 & $0.774(1.01)$ & 0.137 \\
\hline Ethnic ward density & $0.184(2.90)^{* * *}$ & 0.038 & $0.041(0.54)$ & -0.004 \\
\hline Whiteboss & $0.434(1.74)^{*}$ & 0.079 & $0.282(0.92)$ & 0.016 \\
\hline Shiftwork & $0.620(2.71)^{\star * *}$ & 0.157 & $-0.304(1.04)$ & -0.066 \\
\hline Workplace size 500plus & $0.233(0.87)$ & 0.084 & $-0.724(1.93)^{*}$ & -0.087 \\
\hline Trade Union & $-0.142(0.65)$ & -0.050 & $0.371(1.42)$ & 0.056 \\
\hline Public Sector & $-0.601(2.76)^{* * *}$ & -0.122 & $-0.141(0.54)$ & 0.011 \\
\hline Supervised & $-0.420(1.89)^{*}$ & -0.086 & $-0.070(0.28)$ & 0.011 \\
\hline Training & $-0.418(2.03)^{* *}$ & -0.108 & $0.360(1.48)$ & 0.069 \\
\hline No of vehicles in household & $0.126(0.88)$ & 0.026 & $0.034(0.20)$ & -0.001 \\
\hline
\end{tabular}




\begin{tabular}{lll}
\hline Constant & $1.622(1.01)$ & $-3.222(1.58)$ \\
Observations & 734 & 734 \\
LR chi(58)=234.88 & \\
Prob >chi2=0.0000 & \\
Pseudo $\mathrm{R}^{2}=0.1582$ & \\
Log likelihood=-625.12902 & \\
Absolute value of z-statistics in parentheses & \\
${ }^{*}$ significant at $10 \%$ level; ${ }^{* *}$ significant at $5 \%$ level; *** significant at $1 \%$ \\
\hline
\end{tabular}

Notes:

1. Excluded categories: single, Indian, ward unemployment less than $5 \%$ and working for firm with less than 500 employees.

2. The marginal effect for a continuous variable is calculated for a one-unit increase. For dummy variables it represents an average person with that particular characteristic relative to the base characteristic. 
Table 6: Determinants of mismatch (multinomial logit): whites

\begin{tabular}{|c|c|c|c|c|}
\hline & \multicolumn{2}{|c|}{ Over-education } & \multicolumn{2}{|c|}{ Under-education } \\
\hline Age & $\begin{array}{l}\text { Coeff. } \\
-0.069(1.31)\end{array}$ & $\begin{array}{l}\text { Marginal Effect } \\
-0.012\end{array}$ & $\begin{array}{l}\text { Coeff. } \\
-0.021(0.39)\end{array}$ & $\begin{array}{l}\text { Marginal Effect } \\
0.001\end{array}$ \\
\hline Agesq/100 & $0.048(0.72)$ & 0.006 & $0.052(0.81)$ & 0.0068 \\
\hline Male & $-0.004(0.03)$ & -0.004 & $0.042(0.27)$ & 0.009 \\
\hline Married & $0.038(0.21)$ & -0.012 & $0.253(1.37)$ & 0.047 \\
\hline Ward unemployment 5-10\% & $-0.238(1.21)$ & -0.037 & $-0.141(0.76)$ & -0.009 \\
\hline Ward unemployment $10-15 \%$ & $0.264(1.07)$ & 0.072 & $-0.207(0.79)$ & -0.061 \\
\hline Ward unemployment $15-20 \%$ & $0.266(0.52)$ & 0.052 & $0.052(0.09)$ & -0.0123 \\
\hline Ward unemployment $20 \%$ plus & $0.340(0.62)$ & 0.154 & $-1.264(1.51)$ & -0.200 \\
\hline Ethnic ward density & $-0.133(2.11)^{\star *}$ & -0.019 & $-0.095(1.52)$ & -0.009 \\
\hline Shiftwork & $0.226(1.26)$ & 0.0970 & $-0.653(3.16)^{* * *}$ & -0.137 \\
\hline Workplace size 500plus & $-0.022(0.10)$ & -0.003 & $-0.009(0.05)$ & -0.000 \\
\hline Trade Union & $-0.205(1.14)$ & -0.044 & $0.039(0.23)$ & 0.0242 \\
\hline Public Sector & $-0.291(1.64)$ & -0.040 & $-0.225(1.30)$ & -0.0231 \\
\hline Supervise & $-0.690(4.14)^{* * *}$ & -0.151 & $0.210(1.33)$ & 0.097 \\
\hline Training & $-0.097(0.60)$ & -0.0430 & $0.292(1.75)^{*}$ & 0.066 \\
\hline Number of vehicles in household & $0.025(0.23)$ & 0.003 & $0.021(0.19)$ & 0.0023 \\
\hline Constant & $2.230(2.20)^{* *}$ & & $-0.372(0.35)$ & \\
\hline Observations & 1076 & & 1076 & \\
\hline $\begin{array}{l}\text { LR chi(32) }=143.60 \\
\text { Prob >chi2 }=0.000 \\
\text { Pseudo } R^{2}=0.0615 \\
\text { Log likelihood }=-1096.5804 \\
\text { Absolute value of z-statistics in pa } \\
{ }^{*} \text { significant at } 10 \% \text { level; }{ }^{* *} \text { signif }\end{array}$ & $\begin{array}{l}\text { theses } \\
\text { ht at } 5 \% \text { level; * }\end{array}$ & ficant at $1 \%$ & & \\
\hline
\end{tabular}

Notes:

1. Excluded categories: single, ward unemployment less than $5 \%$ and working for firm with less than 500 employees.

2. The marginal effect for a continuous variable is calculated for a one-unit increase. For dummy variables it represents an average person with that particular characteristic relative to the base characteristic. 
Table 7: Determinants of earnings (interval regression)

\begin{tabular}{|c|c|c|c|}
\hline & Non-native non-whites & Native non-whites & Whites \\
\hline Age & $0.039(2.98)^{\star \star \star}$ & $0.090(2.10)^{\star \star}$ & $0.036(3.22)^{\star \star \star}$ \\
\hline Agesq/100 & $-0.042(2.64)^{\star \star *}$ & $-0.124(1.74)^{*}$ & $-0.039(2.77)^{\star \star *}$ \\
\hline Male & $0.117(3.10)^{\star * *}$ & $0.157(2.86)^{\star * *}$ & $0.214(6.01)^{\star \star \star}$ \\
\hline Married & $0.026(0.53)$ & $-0.093(1.60)$ & $-0.031(0.78)$ \\
\hline Years since migration & $0.005(0.59)$ & & \\
\hline Years since migration squared & $-0.000(0.07)$ & & \\
\hline Caribbean & $0.094(1.70)^{*}$ & $0.048(0.68)$ & \\
\hline Pakistani & $0.029(0.50)$ & $0.006(0.06)$ & \\
\hline African-Asian & $0.045(0.96)$ & $-0.080(0.58)$ & \\
\hline Bangladeshi & $0.017(0.24)$ & $-0.044(0.18)$ & \\
\hline Over-educated & $0.073(1.75)^{*}$ & $0.049(0.73)$ & $0.129(2.84)^{\star * \star}$ \\
\hline Under-educated & $-0.313(5.72)^{* * *}$ & $-0.119(1.55)$ & $-0.156(3.59)^{* * *}$ \\
\hline Required education & $0.178(13.49)^{\star \star *}$ & $0.119(5.98)^{\star * \star}$ & $0.207(17.07)^{\star \star *}$ \\
\hline Fluent & $0.102(2.17)^{\star *}$ & $0.052(0.32)$ & \\
\hline Ward unemployment $5-10 \%$ & $0.074(0.89)$ & $-0.008(0.06)$ & $-0.038(0.91)$ \\
\hline Ward unemployment $10-15 \%$ & $0.085(0.97)$ & $0.045(0.34)$ & $-0.002(0.04)$ \\
\hline Ward unemployment $15-20 \%$ & $0.019(0.20)$ & $0.028(0.19)$ & $-0.052(0.44)$ \\
\hline Ward unemployment $20 \%$ plus & $-0.018(0.19)$ & $-0.025(0.16)$ & $0.021(0.16)$ \\
\hline Ethnic ward density & $0.004(0.41)$ & $0.011(0.50)$ & $0.010(0.64)$ \\
\hline Workplace size 500plus & $0.160(3.45)^{\star * *}$ & $0.045(0.57)$ & $0.107(2.33)^{\star *}$ \\
\hline South-east & $0.110(2.90)^{\star * *}$ & $0.204(3.48)^{* * *}$ & $0.162(3.89)^{\star * *}$ \\
\hline Number of vehicles in household & $0.073(2.88)^{\star \star \star}$ & $0.081(2.11)^{\star \star}$ & $0.025(1.01)$ \\
\hline Construction & $0.009(0.15)$ & $-0.018(0.13)$ & $-0.456(5.35)^{* * *}$ \\
\hline Minerals & $0.331(4.54)^{* * *}$ & $0.267(1.70)^{*}$ & $-0.059(0.66)$ \\
\hline Engineer & $0.323(4.38)^{\star * *}$ & $0.193(1.12)$ & $-0.086(0.89)$ \\
\hline Othermfg & $0.379(2.78)^{\star * *}$ & $0.332(1.73)^{*}$ & $-0.136(1.28)$ \\
\hline Hotels & $0.269(3.54)^{* * *}$ & $0.329(2.15)^{\star *}$ & $-0.017(0.20)$ \\
\hline Transport & $0.058(0.74)$ & $0.225(1.51)$ & $-0.164(1.96)^{*}$ \\
\hline Banking & $-0.030(0.43)$ & $-0.041(0.28)$ & $-0.465(5.67)^{\star * *}$ \\
\hline
\end{tabular}




\begin{tabular}{llll}
\hline Others & $-0.074(0.61)$ & $-0.284(1.26)$ & $-0.643(6.21)^{* * *}$ \\
Constant & $3.541(12.52)^{* * *}$ & $3.139(4.80)^{* * *}$ & $4.233(17.94)^{* * *}$ \\
Observations & 919 & 338 & 1037 \\
& LR chi2(30)=519.02 & LR chi2(28)=164.46 & LR chi2(23)=599.35 \\
& Prob>chi2=0.000 & Prob>chi2=0.000 & Prob>chi2=0.000 \\
& Log likelihood=- & Log likelihood=- & Log likelihood=- \\
& 2019.3955 & 738.06889 & 2366.8589 \\
& & \\
Absolute value of z-statistics in parentheses & & \\
${ }^{*}$ significant at 10\% level; ** significant at 5\% level; ${ }^{* * *}$ significant at 1\% & \\
\hline
\end{tabular}

Note:

Excluded categories: single, adequately educated, ward unemployment greater than $20 \%$, working for firm with less than 500 employees, works in energy sector and no qualifications. 
Table 8:Mismatch and supervision (Probit, marginal effects)

\begin{tabular}{|c|c|c|}
\hline & Non-whites & Whites \\
\hline Age & $0.011(0.62)$ & $0.028(2.60)^{\star * *}$ \\
\hline Agesq/100 & $-0.008(0.37)$ & $-0.034(2.56)^{\star *}$ \\
\hline Male & $0.031(0.66)$ & $0.068(2.11)^{* *}$ \\
\hline Married & $-0.029(0.46)$ & $0.043(1.23)$ \\
\hline Years since migration & $-0.009(0.87)$ & \\
\hline Years since migration squared & $0.000(0.78)$ & \\
\hline Caribbean & $0.013(0.20)$ & \\
\hline Pakistani & $-0.030(0.37)$ & \\
\hline African-Asian & $0.080(1.37)$ & \\
\hline Bangladeshi & $0.121(1.13)$ & \\
\hline Over-educated & $0.073(1.30)$ & $0.010(0.24)$ \\
\hline Under-educated & $-0.119(2.02)^{*}$ & $-0.068(1.72)^{*}$ \\
\hline Required education & $0.119(7.79)^{* * *}$ & $0.108(9.88)^{* * *}$ \\
\hline Fluent & $0.226(3.88)^{* * *}$ & \\
\hline Employer size 500plus & $0.001(0.01)$ & $0.036(0.87)$ \\
\hline Public Sector & $-0.057(1.13)$ & $0.033(0.90)$ \\
\hline Trade Union & $-0.041(0.84)$ & $-0.036(1.00)$ \\
\hline \multirow[t]{2}{*}{ Observations } & 534 & 1079 \\
\hline & $\begin{array}{l}\text { LR chi2 }(17)=156.34 \\
\text { Prob }>\text { chi2=0.000 } \\
\text { Pseudo } R^{2}=0.2324 \\
\text { Log likelihood=-258.15935 }\end{array}$ & $\begin{array}{l}\text { LR chi2(20) }=176.30 \\
\text { Prob }>\text { chi2 }=0.000 \\
\text { Pseudo } R^{2}=0.1204 \\
\text { Log likelihood }=-643.81936\end{array}$ \\
\hline $\begin{array}{l}\text { Absolute value of z-statistics in } \\
* \text { significant at } 10 \% \text { level; } * * \text { s }\end{array}$ & $\begin{array}{l}\text { ntheses } \\
\text { cant at } 5 \% \text { level; ***signific }\end{array}$ & \\
\hline
\end{tabular}

Notes:

1. Dependent variable: Supervise $(=1$ if supervised anyone $=0$ otherwise).

2. Excluded categories: single, Indian, adequately educated and working for firm with less than 500 employees.

3. The marginal effect for a continuous variable is calculated for a one-unit increase. For dummy variables it represents an average person with that particular characteristic relative to the base characteristic. 
Table 9: Mismatch and training (Probit, marginal effects)

\begin{tabular}{lll}
\hline & Non-whites & Whites \\
\hline Age & $0.0140 .76)$ & $0.008(0.78)$ \\
Agesq/100 & $-0.019(0.86)$ & $-0.014(1.06)$ \\
Male & $0.002(0.04)$ & $0.055(1.73)^{*}$ \\
Married & $-0.051(0.78)$ & $0.042(1.19)$ \\
Years since migration & $-0.001(0.06)$ & \\
Years since migration squared & $0.000(0.20)$ & \\
Caribbean & $0.219(2.85)^{* * *}$ & \\
Pakistani & $-0.002(0.02)$ & \\
African-Asian & $0.049(0.81)$ & \\
Bangladeshi & $0.070(0.68)$ & $0.103(2.50)^{* *}$ \\
Over-educated & $0.132(2.30)^{* *}$ & $-0.065(1.55)$ \\
Under-educated & $-0.052(0.75)$ & $0.101(9.16)^{* * *}$ \\
Required education & $0.103(6.46)^{* * *}$ & \\
Fluent & $0.097(1.55)$ & $0.112(2.61)^{* *}$ \\
Employer size 500plus & $0.076(1.17)$ & $0.066(1.82)^{*}$ \\
Public Sector & $0.027(0.50)$ & $0.113(3.19)^{* * *}$ \\
Trade Union & $0.015(0.29)$ & 1079 \\
Observations & 536 & LR chi2 $(17)=173.30$ \\
& LR chi2(17) $=118.17$ & Prob>chi2 $=0.000$ \\
& Prob>chi2=0.000 & Pseudo $R^{2}=0.1183$ \\
& Pseudo $R^{2}=0.1655$ & Log likelihood=-646.00052
\end{tabular}

Absolute value of z-statistics in parentheses

* significant at $10 \%$ level; $* *$ significant at $5 \%$ level; $* * *$ significant at $1 \%$

Notes:

1. Dependent variable: Training $(=1$ if received training for the workplace $=0$ otherwise)

2. Excluded categories: single, Indian, adequately educated and working for firm with less 500 employees.

3. The marginal effect for a continuous variable is calculated for a one-unit increase. For dummy variables it represents an average person with that particular characteristic relative to the base characteristic. 
References

Alba-Ramirez, A. (1993). "Mismatch in the Spanish Labour Market: Overeducation?", Journal of Human Resources, Vol. 28, No. 2, pp. 259-278.

Alpin, C, Shacklelton, J.R. and S Walsh. (1998). "Over and Under-Education in the UK Graduate Labour Market", Studies in Higher Education, Vol. 23, pp. 17-34.

Arnott, R.(1998). "Economic Theory and the Spatial Mismatch Hypothesis", Urban Studies, Vol. 35, pp. 1171-1185

Battu, H, Belfield, CR and P Sloane. (2000) Over-education: How Sensitive are the Measures?. National Institute Economic Review, No. 171, pp. 82-93..

Battu, H. and Sloane, P. Overeducation and Crowding out in Britain, in Borghans, L. and de Grip, A. (2000). The Overeducated Worker, Edward Elgar, Cheltenham.

Blackaby, D., Leslie, D., Murphy, P. and O’Leary, N. (1998). "The Ethnic Wage Gap and Employment Differentials in the 1990s: Evidence from Britain", Economics Letters, Vol. 58, pp. 97-103.

Blackaby, D., Leslie, D., Murphy, P. and O’Leary, N. (1999). "Unemployment among Britain's Ethnic Minorities", The Manchester School, Vol. 67, No. 1, pp. 1-20.

Cabinet Office, Performance and Innovation Unit, (2002), Ethnic minorities and the labour market: interim analytical report.

Chiswick, B.R. and Miller, P.W. (1995). "The Endogeneity between Language and Earnings: An International Analyses", Journal of Labor Economics, Vol. 13, No.2, pp.246-288.

Connor, H.,la Valle, N.D., N.D. Tackey and Perryman, S. (1996). Differences by degrees: ethnic minority graduates, Brighton, Institute of Employment Studies.

Duncan, G.J., and Hoffman, S.D. (1981). "The Incidence and Wage Effects of Overeducation", Economics of Education Review, Vol. 1, No.1, pp.75-86.

Dustmann, C. and Fabbri, F. (2000). "Language Proficiency and Labour Market Performance if Immigrants in the UK", IZA Discussion Paper, No. 156.

Edin et al. (2000). "Ethnic Enclaves and the Economic Success of Immigrants: Evidence from A Natural Experiment", mimeo

Groot, Wim and Maassen van den Brink, Henriette. (2000). "Overeducation in the Labour Market: A Meta-Analysis", in Oosterbeek, Hessel (Ed.), The Economics of Over- and Underschooling. Special issue of Economics of Education Review, Vol. 19, No.2, pp.149158.

Hartog, J. (2000). "Over-education and earnings: where are we, where should we go?", Economics of Education Review, Vol. 19, pp. 131-147.

Kain, J.(1968). "Housing Segregation, Negro Employment and Metropolitan Decentralisation", Quarterly Journal of Economics, Vol. 82, pp.175-197.

Kiker, B.F.,Santos, M.C. and de Oliveira, M.M. (1997). "Overeducation and Undereducation: Evidence for Portugal," Economics of Education Review, Vol. 16(2), pp. 111-125.

Leslie, D. (1998), “An Investigation of Racial Disadvantage”, Manchester University Press, Manchester and New York.

Leslie, D. and Drinkwater, S. (1999), "Staying on in full-time education: Reasons for higher participation among ethnic minority males and females", Economica, Vol. 66, pp. 63-77.

Lindley, J. (2002). "The English Language Fluency and Earnings of Ethnic Minorities in Britain", Scottish Journal of Political Economy, Vol.49, No. 4, pp.467-487.

Modood,T., Berthoud, R., Lakey, J., Nazroo, J., Smith, P., Virdee, S., and Beishon, S. (1997). Ethnic Minorities in Britain: Diversity and Disadvantage, Policy Studies Institute, London.

McCormick, B. (1986). "Employment Opportunities, Earnings and the Journey to Work of Minority Workers in Great Britain", Economic Journal, Vol. 96, No. 382, pp.375-397.

Owen, D. Green, A. Pitcher, J. and Maguire, M. (2000) Minority Ethnic Participation and Achievements in Education, Training and the Labour Market, Department for Education and Employment, Research Brief No. 225.

Peach, C (1996). "Does Britain Have Ghettos?", Transactions of the Institute of British Geographers, Vol. 21, pp. 216-235. 
Raphael, S. and Stoll, M. (2000), Can Boosting Minority Car-Ownership Rates Narrow InterRacial Employment Gaps?". Berkeley Program on Housing and Urban Policy. Working Papers: Working Paper W00-002.

Sattinger, M (1993). "Assignment Models of the Distribution of Earnings", Journal of Economic Literature, Vol. 31(2), pp. 851-880.

Shields, M.A and Wheatley Price, S. (2002). "The English Language Fluency and Occupational Success of Ethnic Minority Immigrant Men Living in English Metropolitan Areas", Journal of Population Economics, Vol. 15, pp. 137-160.

Sicherman, N. (1991). "Overeducation in the Labor Market", Journal of Labor Economics, Vol. No.2, pp.101-122.

Sloane, P, Battu, H and Seaman, P. (1999), "Overeducation, Undereducation and the British Labour Market", Applied Economics, Vol.31, No.11, pp. 1437-54.

Stewart, M. (1983)"On Least Squares Estimation when the Dependent Variable is Grouped", Review of Economic Studies, Vol. 50, 737-53.

Tsang, M. C., Rumberger, R.W. and Levin, H.M. (1991). "The Impact of Surplus Schooling on Workers Productivity, Industrial Relations, 30(2), 209-228.

Weinberg, B.A. (2000). "Black Residential Centralisation and the Spatial Mismatch Hypothesis", Journal of Urban Economics, Vol. 48, pp.110-134. 


\section{IZA Discussion Papers}

\begin{tabular}{|c|c|c|c|c|}
\hline No. & Author(s) & Title & Area & Date \\
\hline 634 & $\begin{array}{l}\text { A. D. Kugler } \\
\text { R. M. Sauer }\end{array}$ & $\begin{array}{l}\text { Doctors Without Borders: The Returns to an } \\
\text { Occupational License for Soviet Immigrant } \\
\text { Physicians in Israel }\end{array}$ & 1 & $11 / 02$ \\
\hline 635 & $\begin{array}{l}\text { M. Karanassou } \\
\text { D. J. Snower }\end{array}$ & An Anatomy of the Phillips Curve & 3 & $11 / 02$ \\
\hline 636 & $\begin{array}{l}\text { M. Karanassou } \\
\text { H. Sala } \\
\text { D. J. Snower }\end{array}$ & $\begin{array}{l}\text { A Reappraisal of the Inflation-Unemployment } \\
\text { Tradeoff }\end{array}$ & 3 & $11 / 02$ \\
\hline 637 & $\begin{array}{l}\text { H. Bonin } \\
\text { W. Kempe } \\
\text { H. Schneider }\end{array}$ & $\begin{array}{l}\text { Household Labor Supply Effects of Low-Wage } \\
\text { Subsidies in Germany }\end{array}$ & 3 & $11 / 02$ \\
\hline 638 & $\begin{array}{l}\text { L. McLeod } \\
\text { M. R. Veall }\end{array}$ & $\begin{array}{l}\text { The Dynamics of Food Deprivation and Overall } \\
\text { Health: Evidence from the Canadian National } \\
\text { Population Health Survey }\end{array}$ & 2 & $11 / 02$ \\
\hline 639 & G. Saint-Paul & Are Intellectual Property Rights Unfair? & 3 & $11 / 02$ \\
\hline 640 & $\begin{array}{l}\text { J. Hartog } \\
\text { N. Jonker } \\
\text { H. van Ophem }\end{array}$ & $\begin{array}{l}\text { Dual Track or Academic Route for Auditors: } \\
\text { Does It Matter? }\end{array}$ & 6 & $11 / 02$ \\
\hline 641 & $\begin{array}{l}\text { J. Hartog } \\
\text { L. Diaz Serrano }\end{array}$ & $\begin{array}{l}\text { Earning Risk and Demand for Higher Education: } \\
\text { A Cross-Section Test for Spain }\end{array}$ & 2 & $11 / 02$ \\
\hline 642 & $\begin{array}{l}\text { J. Hartog } \\
\text { A. Zorlu }\end{array}$ & $\begin{array}{l}\text { The Effect of Immigration on Wages in Three } \\
\text { European Countries }\end{array}$ & 1 & $11 / 02$ \\
\hline 643 & $\begin{array}{l}\text { A. Björklund } \\
\text { M. Sundström }\end{array}$ & $\begin{array}{l}\text { Parental Separation and Children's Educational } \\
\text { Attainment: A Siblings Approach }\end{array}$ & 6 & $11 / 02$ \\
\hline 644 & $\begin{array}{l}\text { J. D. Brown } \\
\text { J.S. Earle }\end{array}$ & $\begin{array}{l}\text { Job Reallocation and Productivity Growth Under } \\
\text { Alternative Economic Systems and Policies: } \\
\text { Evidence from the Soviet Transition }\end{array}$ & 4 & $11 / 02$ \\
\hline 645 & $\begin{array}{l}\text { M. Karanassou } \\
\text { H. Sala } \\
\text { D. J. Snower }\end{array}$ & $\begin{array}{l}\text { Long-Run Inflation-Unemployment Dynamics: } \\
\text { The Spanish Phillips Curve and Economic Policy }\end{array}$ & 3 & $11 / 02$ \\
\hline 646 & $\begin{array}{l}\text { L. Graham } \\
\text { D. Snower }\end{array}$ & The Return of the Long-Run Phillips Curve & 3 & $11 / 02$ \\
\hline 647 & $\begin{array}{l}\text { C. Grund } \\
\text { D. Sliwka }\end{array}$ & Envy and Compassion in Tournaments & 1 & $11 / 02$ \\
\hline 648 & $\begin{array}{l}\text { C. Schnabel } \\
\text { T. Schank } \\
\text { J. Wagner }\end{array}$ & $\begin{array}{l}\text { Works Councils - Sand or Grease in the } \\
\text { Operation of German Firms? }\end{array}$ & 3 & $11 / 02$ \\
\hline 649 & $\begin{array}{l}\text { J. van Ours } \\
\text { J. Veenman }\end{array}$ & $\begin{array}{l}\text { From Parent to Child: Early Labor Market } \\
\text { Experiences of Second-Generation Immigrants } \\
\text { in the Netherlands }\end{array}$ & 1 & $11 / 02$ \\
\hline 650 & $\begin{array}{l}\text { H. Battu } \\
\text { P. J. Sloane }\end{array}$ & Overeducation and Ethnic Minorities in Britain & 2 & $11 / 02$ \\
\hline
\end{tabular}

